\title{
Collagen: Animal Sources and Biomedical Application
}

\author{
K. S. Silvipriya, K. Krishna Kumar*, A. R. Bhat, B. Dinesh Kumar, Anish John, Panayappan lakshmanan \\ St James Hospital Trust Pharmaceutical Research Centre, Chalakudy-680307, Kerala, India. \\ St James College of Pharmaceutical Sciences, Chalakudy-680307, Kerala, India.
}

\section{ARTICLE INFO}

Article history:

Received on: 19/12/2014

Revised on: 21/01/2015

Accepted on: 14/02/2015

Available online: 28/03/2015

Key words:

Collagen; animal source;

Pharmaceutical application.

\begin{abstract}
Collagen is the sole most profuse protein in the animal kingdom. It has been subjected to various studies from time immemorial. Its applications are numerous and have been extracted from various sources such as land animals (mainly bovine and porcine) and birds. Although collagen sources are abundant the outbreak of varied diseases among land animals posed a threat to its utilization in our daily life. Thus a probe for an alternative source began which in turn revealed the immense untapped marine source. The present article deals with a brief description of collagen its characteristics,chemistry,common extraction procedure, application in various fields and sources. A lot of studies have been carried out on various land animals, birds and marine organisms and this review sums up the work performed to date in a concise manner.
\end{abstract}

\section{INTRODUCTION}

The word collagen is derived from a Greek word where "kola" means gum and "gen" means producing. Collagen is a fibrous structural protein present in the extracellular matrix and connective tissue of animals (Ramshaw et al., 2009).

It is the sole most profuse protein in the animal kingdom. It is absent in plants and unicellular organisms where polysaccharides and cellulose takes up its role. In case of invertebrates it is present in their body walls and cuticles. Collagen comprises $25-30 \%$ of the protein content of the whole body especially in mammals (Muller \& Werner, 2003). It is found in the corneas, bones, blood vessels, cartilage, dentin of teeth, etc.

In fibrous tissues such as the skin, tendons and ligaments it is found as elongated fibrils. It constitutes $1-2 \%$ of muscle tissue where it is a foremost component of the endomysium. Collagen is formed mostly by the fibroblast of connective tissue and also by variety of other epithelial cells (Lullo et al., 2002; Kadler et al., 2007).

\footnotetext{
* Corresponding Author

Email: stjamespharmacyproject@gmail.com
}

\section{STRUCTURE OF COLLAGEN}

The basic structural unit of collagen is composed three polypeptide chain arranged in the form of a triple helix with two identical chains $(\alpha 1)$ and the third which differs to some extent in its chemical composition $(\alpha 2)$. Thus it is a heteropolymer. Each chain has 1050 amino acids wound around one another in a typical right-handed helical structure which is $300 \mathrm{~nm}$ long. Its diameter is about $1.5 \mathrm{~nm}$ and has a molecular weight of around 2,90,000. Its structure has a repeating motif Gly-X-Y, where X and Y can be any amino acid, but mostly are proline and hyroxyproline. At each third amino acid position glycine is crucial in order to permit a firm packaging of the $3 \alpha$ chains in the tropocollagen molecule. Collagen is packed into hexagonal and quasi hexagonal shapes forming fibrillar collagen types. This packing may be sheet-like or microfibrillar. Microscopically collagen is found as elongated fibrils (Szpak\& Paul, 2011).

\section{TYPES OF COLLAGEN}

Nearly 28 types of collagen have been identified so far which is composedof 46 distinct polypeptide chains. All of them have a characteristic triple helix but the length of the helix and the size and nature of non-helical portion varies from one to another type (Miller, 1984). Among these the 5 most common ones are: 
Collagen I: Skin, bone ,teeth, tendon, ligament, vascular ligature, organs (main constituent of the organic part of bone)

Collagen II: Eyes and cartilage (main constituent of cartilage).

Collagen III: Reticulate (main constituent of reticular fibers), skin, muscle, blood vessels.

Collagen IV: Forms the epithelium-secreted layer of the basement membrane and the basal lamina.

Collagen V: Hair, cell surfaces and placenta.

$90 \%$ of the collagen in the body is of type I followed by type II and III. Reason for the abundance of Type I collagen is due to its wide prevalence in almost all connective tissues (Cheah, 1985).

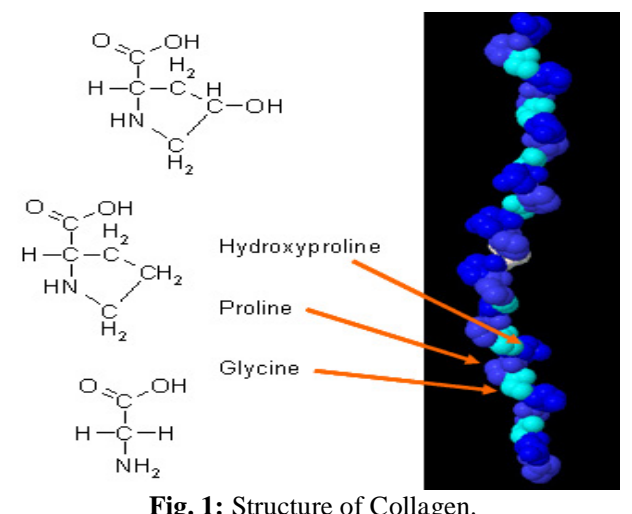

\section{CHARACTERISTICS OF COLLAGEN}

Supports most of the tissues in the form of extracellular matrix and gives structure to the cells. It has great tensile strength exhibited by its presence in tendons, bones, cartilage, fascia, etc. It provides elasticity and strength to the skin and helps in tissue and organ development. Collagen provides protection to skin by inhibiting the absorption of toxins and pathogens (Fratzl, 2008). It has role in biological functions of a cell (cell survival, proliferation and differentiation), helps in healing of damaged bones or blood vessels and maintains structural integrity (Buehler, 2006).

\section{COLLAGEN SOURCES FROM ANIMAL}

\section{Bovine}

It makes use of the skin and bone of cow. It is one of the major industrial sources of collagen. Due to the outbreak of diseases such as BSE, TSE,FMD especially mad cow disease,which pose a threat to the humans, researchers are in search for an alternative safer source of collagen. One of the major disadvantages of bovine collagen is that nearly $3 \%$ of the population is allergic to it causing a hindrance in its usage. Bovine Achilles tendon is used industrially to obtain type I collagen. Type IV is obtained from the placental villi and type II from nasal or articular cartilage. Bovine is made use of in different development stages such as fet al bovine dermis used for tendon reinforcement, skin and wound healing (in the form of collagen matrix); neonatal bovine dermis is used for hernia repair, plastic and reconstructive surgery; adult bovine pericardium for hernia repair and muscle flap reinforcement (Parenteau-Bareil et al., 2010; Ahuja et al., 2012).

\section{Porcine}

The skin and bones of pigs are utilized. This source is widely used for obtaining collagen for industrial purpose. Since porcine collagen is almost similar to human collagen it does not cause much allergic response when used. But just like the bovine source the setback of zoonosis poses a risk of contamination and pigs are forbidden due to religious constrains. Adult porcine dermis and small intestinal mucosa is used for tendon reinforcement, hernia repair, skin and wound healing, plastic and reconstructive surgery (Cortial et al., 2006).

\section{Marine}

Marine source is found to be the safest source for obtaining collagen presently. Another reason for approving this source is due to the belief that "life originated from marine". Collagen extraction from animal source is complex, time consuming and expensive. The yield obtained is also lower when compared to other sources (approximately $12 \mathrm{~g}$ of collagen per 1 $\mathrm{kg}$ of the raw material used). Due to the concern over adverse inflammatory and immunologic response and prevalence of various diseases among land animals which causes health complications, marine sources have started to be researched (Addad et al., 2011; Perumal, 2013; Exposito et al., 1999, 2002;).

Marine source has got ample advantages over the land animal sources such as:

$>$ Free of zoonosis such as BSE, TSE and FMD

$>$ High content of collagen

$>$ Environment friendly

$>$ Has lower body temperature than animals thereby aids in greater absorption

$>$ Greater absorption due to low molecular weight.

$>$ Less significant religious and ethical constrains

$>$ Minor regulatory and quality control problems

$>$ Presence of biological contaminants and toxins almost negligible

$>$ Low inflammatory response

$>$ Less immunogenic

$>$ Metabolically compatible

This source includes the use of marine invertebrates and vertebrates such as fishes, star fish, jellyfish, sponges, sea urchin, octopus, squid, cuttlefish, sea anemone and prawn (Krishnan \& Subramanian \& Lin, 2008; Sugiura et al., 2009; Song et al., 2006; Strawich et al., 1971).

\section{Fishes}

The bones, skin, fins, scales of fresh or salt water fishes are mainly used for this purpose. This in turn helps to reduce environmental pollution as these are the considered a waste during 
fish processing. Study of collagen from marine origin comprises of marine vertebrates and invertebrates. Vertebrates include mainly the fishes (Liang et al., 2010; Tzaphlidou and Berillis, 2002). Collagen mainly type I was obtained from the skin of

- Gadus morhua

- $\quad$ silver carp Hypophthal michthysmolitrix

- Japanese sea-bass,

- chub mackerel bullhead shark,

- Sole fish;

\section{Bone of}

- Thunnus obesus

- $\quad$ skipjack tuna,

- Japanese sea-bass,

- ayu,

- yellow sea bream,

- $\quad$ horse mackerel; fin of

- Japanese sea-bass scales of

- Pagrus major

- Oreochromis niloticas

- Carp

\section{OTHER ANIMAL SOURCES}

It includes chicken, kangaroo tail, rat tail tendon, duck feet, equine tendon (horse),alligators bone and skin, birds feet, sheep skin (ovine source), frog skin and sometimes even from humans (Johnson et al., 1999; Wood et al., 2008). Recombinant human collagen is used which lower immunogenicity has compared to other sources. Adult equine pericardium is used for tendon reinforcement, skin and wound healing and hernia repair. Type I and II collagen is isolated from equine skin, articular cartilage and flexor tendon (Cortial et al., 2006). Collagen type I,II,III and V were obtained from chicken neck among which type I was predominant. Chicken feet are an abundant source of collagen. Type IX is also found in the chicken embryo sternal cartilage and type I and III from its skin, type IV from its muscular tissues (Hutmacher, 2000; Quereshi, 2010; Mayne et al., 1980). Type I collagen was also obtained from the fallopian tube of bull frog (Wang et al., 2011). From invertebrates tissue of Archaeogastropod, Neritacrepidularia, gastropod collagen was characterized (Palpandi et al., 2010).

\section{EXTRACTION PROCEDURE OF COLLAGEN FROM ANIMAL SOURCE}

- Maintenance of raw material at $-25^{\circ} \mathrm{C}$ or $-4^{\circ} \mathrm{C}$

- Removal of non-collagenous pigments and proteins using sodium chloride/sodium hydroxide/ calcium hydroxide

- Demineralization with hydrochloric or acetic acid solution

- Digestion with acid or enzyme

- Morphological analysis

- Extraction of collagen including dialysis with acetic acid or disodium hydrogen phosphate

- Amino acid analysis, electrophoresis, denaturation temperature analysis, X-ray diffraction analysis, UV-visible spectra (Mocan et al., 2011).

\section{APPLICATIONS OF COLLAGEN}

\section{Pharmaceutical industries}

Collagen is used in pharmaceutical industries as microparticles, injectable dispersions, shields in ophthalmologysponges, drug delivery system. Its application in the pharmaceutical as well as biomedical field is due to its characteristics such as weak antigenicity, cell attachment ability, biodegradability and biocompatibility (Leitinger and Hohenester, 2007).

\section{Tissue engineering}

Collagen type I is considered to be the gold standard for this field due to its high biocompatibility. It is used as the basic matrix for cell culture system. Biomaterials based on collagen are widely used in tissue engineering such as injectable matrices, scaffolds intended for bone regeneration etc. These biomaterials are produced mainly from fibril- forming collagen which includes type I,II,III,V,XI (Oliveira et al., 2009; Parenteau-Bareil et al., 2010).

\section{Biomedical industry}

For tissue regeneration scaffolds are needed. Collagen serves the purpose in the form of decellularised ECM. Such acellular collagen matrix is obtained from porcine or human dermis and swine sub-mucosa or intestine. Collagen scaffolds serve numerous purposes such to visualize cells in nervous system.

Table 1: Collagen from marine invertebrates.

\begin{tabular}{|c|c|c|c|}
\hline Marine Invertebrates & Scientific Name & Targeted Tissue & Reference \\
\hline \multirow{3}{*}{ JELLYFISH } & ChrysaoraQuinquecirrha & & Hoyer et al., 2014 \\
\hline & Aurelia Aurita & Whole tissues & \\
\hline & RhopilemaEsculentum & & Jin-Feng et al., 2010 \\
\hline OCTOPUS & Octopus Vulgaris & Skin & Kimura et al., 1981 \\
\hline \multirow{2}{*}{ CUTTLEFISH } & $\begin{array}{l}\text { SepiellaInermis } \\
\text { Senia Pharannis }\end{array}$ & Outer skin & \multirow[t]{2}{*}{ Shanmugamet al 2012} \\
\hline & Sepia Officinalis & Cranial cartilage, cornea & \\
\hline SEA URCHIN & $\begin{array}{l}\text { HemicentrotusPulcherrimus } \\
\text { StrongylocentrotusPurpuratus }\end{array}$ & Embryonic organs & $\begin{array}{l}\text { Mizoguchi et al., } 1989 \\
\text { Crise-Benson \& Carl-Benson, } 1979\end{array}$ \\
\hline \multirow{2}{*}{$\begin{array}{l}\text { STARFISH } \\
\text { CRAB }\end{array}$} & $\begin{array}{l}\text { Asteriasamurensis } \\
\text { AcanthasterPlanci }\end{array}$ & & Ka-jeong et al., 2009 \\
\hline & Scylla Serrata & & Deshmukh\&Nimni, 1971 \\
\hline
\end{tabular}


models, study of character of cancer cells, in ex-vivo cultivation of organsas 3-D models for various diseases etc (Badylak, 2004; Giingras et al., 2008; Che et al., 2006).

\section{Medical field}

In modern medicine collagen based scaffolds play a vital role. It helps in cartilage and bone reconstruction. Scaffolds are implanted in cases of grafting failure or avoidance and when such defects rise to an elevated level. In vascular and cardiac reconstruction, collagen in the form of tissue engineered blood vessels is grafted successfully in the patients. Collagen based dressing in the form of sponge for wounds or burns in the form of collagen films and powders, surgical suture. In urogenital disorders, corneal defects, study of neural migration, dental purpose, bone grafting, arthritis and obesity (Sanz-Herrera et al., 2011; Cunniffe and Brien 2011). Collagen has various applications in the departments such as Cardiology (heart valve)Dermatology (for skin replacement, augmentation of soft tissue, skin tissue engineering, artificial skin dermis)Surgery (as hemostatic agent, wound repair and dressing, nerve repair, blood vessel prostheses) Orthopaedic (tendon, bone and ligament repair, cartilage reconstruction) Ophthalmology (corneal grafts, contact lenses) Urology (dialysis membrane hemodialysis, sphincter repair) Vascular (vascular graft, vessel replacement) (Rose \& Oreffo, 2002).

\section{CONCLUSION}

Collagen is the most abundant protein found in the animal kingdom. Different types of collagen have already been identified and many more are yet to be found out. The role the collagen plays in our body is chiefly due to its characteristic triple helix. Each type of collagen exhibits different distinctiveness based on their structural features. Collagen is obtained from numerous sources primarily from land animals and birds. Due to the outbreak of diseases such as BSE, TSE, and FMDetc among the land animals, search for an alternative source of collagen became indispensible. Marine sources have started to be explored as a reliable and economic source of collagen. It includes marine fishes, starfish, sponges, jelly fish, squid, etc. The various studies performed till date proves it to be a promising source. Collagen has widespread applications in numerous fields such as pharmaceutical, medical, biomedical, food industry, cosmetics, etc. A wide range of applications of collagen have by now been recognized and many more are waiting be revealed in future. Research is still on its way to identify the various unexplored sources of collagen.

\section{ACKNOWLEDGMENT}

The authors are expressed sincere thanks to Indian Council of Medical Research (ICMR), New Delhi, for their financial assistance regarding our research work on "Development of Collagen Scaffold from Wastage of Fish Scales".

\section{REFERENCE}

Ramshaw JA, Peng Y, Glattauer V, Werkmeister JA. Collagens as biomaterials. J. Mater. Sci. Mater. Med. 2009; 20 (1): S3-S8.

Muller, Werner EG. The Origin of Metazoan Complexity: Porifera as Integrated Animals. Integrated Computational Biology, 2003; 43 (1): 30-10.

Lullo DD, Gloria A, Shawn SM,Jarmo K,Ala-Kokko, Leena, Antonio S, James D. Mapping the Ligand-binding Sites and Diseaseassociated Mutations on the Most Abundant Protein in the Human, Type I Collagen. J. Biol. Chem. 2002; 277 (6): 4223-4231.

Kadler KE, Baldock C, Bella J, Boot-Handford RP. Collagens at a glance. Journal of cell science, 2007; 120, 1955-1958.

Szpak and Paul. Fish bone chemistry and ultrastructure: implications for taphonomy and stable isotope analysis. Journal of Archaeological Science, 2011; 38 (12): 3358-3372.

Miller, EJ. 1984. Biomedical and industrial application of collagen; In: Extracellular Matrix Biochemistry, K. A. Piez and A. H. Reddi, eds. Elsevier, New York. pp. 41-81.

Cheah KSE. Collagen genes and inherited connective tissue disease. Biochem. J. 1985; 229, 287-303.

Fratzl P. 2008. Collagen: Structure and Mechanics. New York: Springer. p 1-496.

Buehler, MJ. Nature designs tough collagen: Explaining the nanostructure of collagen fibrils. PNAS. 2006; 103 (33): 12285-12290.

Parenteau-Bareil R, Gauvin R, Berthod F. Collagen-Based Biomaterials for Tissue Engineering Applications. Materials. 2010; 3 (3):1863-1887.

Ahuja T, Dhakray V, Mittal M, Khanna P, Yadav B, Jain M. Role Of Collagen In The Periodontal Ligament - A Review. The Internet Journal of Microbiology. 2012; 10: 1-10.

Cortial D, Gouttenoire J, Rousseau CF, Ronziere MC, Piccardi N, Msika P, Herbage D, Mallein-Gerin F, Freyria AM. Activation by IL-1 of bovine articular chondrocytes in culture within a 3D collagen-based scaffold. An in vitro model to address the effect of compounds with therapeutic potential in osteoarthritis. Cartilage 2006,14,631-640.

Addad S, Jean-Yves E, Faye C, Sylvie Ricard-Blum S, Lethia C. Isolation, Characterization and Biological Evaluation of Jellyfish Collagen for Use in Biomedical Applications. Mar Drugs. 2011; 9 (6): 967-983.

Krishnan S, Perumal P. Preparation and Biomedical Characterization of Jellyfish (ChrysaoraQuinquecirrha) Collagen from Southeast Coast of India. International Journal Of Pharmacy and Pharmaceutical Sciences, 2013; 5 (3): 698-701.

Exposito JY, Cluzel C, Garrone R, Lethias C. Evolution of collagens. Anat. Rec. 2002; 268: 302-316.

Exposito JY, Cluzel C, Garrone R, Lethias C, Garrone Q. Short chain collagens in sponges are encoded by a family of closely related genes. J. Biol. Chem. 1999; 266: 21923-21928.

Subramanian A, Lin HY. Crosslinked chitosan: its physical properties and the effects of matrix stiffness on chondrocyte cell morphology and proliferation. J. Biomed. Mater. Res. 2008; 75A:742-753.

Sugiura, H, Yunoki S, Kondo E, Ikoma T, Tanaka J, Yasuda K. In vivo biological responses and bioresorption of tilapia scale collagen as a potential biomaterial. J. Biomater. Sci. Polym. 2009; 20, 1353-1368.

Song E, Yeon Kim, ChunT, Byun HJN, Lee Y. M. Collagen scaffolds derived from a marine source and their biocompatibility. Biomaterials 2006; 27: 2951-2595.

Strawich E, Nimni ME. Properties of a collagen molecule containing three identical components extracted from bovine articular cartilage. Biochemistry, 1971; 10 (21):3905-3911.

Liang J, Pei XR, Wang N, Zhang ZF, Wang JB, Li Y. Marine collagen peptides prepared from chum salmon (Oncorhynchusketa) skin extend the life span and inhibit spontaneous tumor incidence in SpragueDawley Rats. J Med Food. 2010; 13 (4): 757-770.

Tzaphlidou M, Berillis P. Structural alterations caused by lithium in skin and liver collagen using an image processing method Journal of Trace and Microprobe Techniques, 2002; 20 (4): 493-504. 
Hoyer B, Bernhardt A, Lode A, Heinemann S, Sewing J, Klinger M, Notbohm H, Gelinsky M. Jellyfish collagen scaffolds for cartilage tissue engineering. Acta Biomater. 2014; 10 (2): 883-892.

Jin-Feng D,Xiu-Rong SU,Chun-Dan Z. Extraction of collagen from jellyfish (rhopilemaesculentum) and wound healing-promoting effect in mouse. J. Food Science, 2010, 31 (24): 19-23.

Kimura S, Takema Y, Kubota M. Octopus skin collagen. Isolation and characterization of collagen comprising two distinct alpha chains. J Biol Chem. 1981; 25;256 (24):13230-13234.

Shanmugam V, Ramasamy P, Subhapradha N, Sudharsan S, Seedevi P, Moovendhan M, Krishnamoorthy J, Shanmugam A, Srinivasan A. Extraction, structural and physical characterization of type I collagen from the outer skin of Sepiellainermis. African Journal of Biotechnology, 2012; 11 (78): 14326-14337.

Mizoguchi H, Fujiwara A, Yasumasu IK. Synthesis of Collagen-Like Proteins in Embryonic Organs of the Sea Urchin, Hemicentrotus pulcherrimus (sea urchin embryolcollagen synthesis lembryonic organ/ embryogenesis). Development Growth \& Differentiation, 1989; 31 (2), 189-196.

Crise-Benson N, Carl-Benson S. Ultra-structure of collagen in sea urchin embryos. Roux's archives of developmental biology, 1979; 186: $65-70$

Ka-jeong L, Park HY, Kim YK, Park JI, Yoon HD. Biochemical Characterization of Collagen from the Starfish Asteria samurensis. J. Korean Soc. Appl. Biol. Chem. 2009; 52 (3): 221-226.

Deshmukh K, Nimni ME. Characterization of the aldehydes presents on the cyanogen bromide peptides from mature rat skin collagen. Biochemistry. 1971;10 (9):1640-1647.

Johnson KA, Rogers G, Roe SC, Howlett CR, Clayton M, MilthorpeMK, Schindhelm K. Nitrous acid pretreatment of tendon xenografts cross-linked with glutaraldehyde and sterilized with gamma irradiation. Biomaterials. 1999;20: 1003-1015.

Wood A, Ogawa M, Portier M, Schexnayder M, Shirley M, Losso JN. Biochemical properties of alligator (Alligator mississippiensis) bone collagen. Comp. Biochem. Physiol. Biochem. Mol. Biol. 2008;151:246-249.

Cortial D1, Gouttenoire J, Rousseau CF, Ronzière MC, Piccardi N, Msika P, Herbage D, Mallein-Gerin F, Freyria AM. Activation by IL-1 of bovine articular chondrocytes in culture within a 3D collagen-based scaffold. An in vitro model to address the effect of compounds with therapeutic potential in osteoarthritis. Osteoarthritis Cartilage, 2006; 14 (7): $631-640$

Hutmacher DW. Scaffolds in tissue engineering bone and cartilage. Biomaterials. 2000; 21: 2529-2543.

Quereshi S, Mhaske A, Raut D, Singh R, Mani A, Patel J. Biotechnology Extraction And Partial Characterization Of Collagen From Different Animal Skins. Recent Research in Science and Technology 2010; 2 (9): 28-31.
Mayne R, Zettergren JG. Type IV collagen from chicken muscular tissues. Isolation and characterization of the pepsin-resistant fragments. Biochemistry, 1980; 19 (17): 4065-4072.

Wang T, Lin S, Shen Y, Liu S, Wang-McCall T, Chin M, Lin T, Yang C, Wu W, Yang C. Type I collagen from bullfrog (Ranacatesbeiana) fallopian tube. African Journal of Biotechnology, 2011; 10 (42): 84148420 .

Palpandi C, Ramasamy $\mathrm{P}$, Rajinikanth $\mathrm{T}$, Vairamani $\mathrm{S}$, Shanmugam A. Extraction of Collagen from Mangrove ArcheaogastropodNerita (Dostia)crepidularia Lamarck, 1822. AmericanEurasian Journal of Scientific Research, 2010; 5 (1): 23-30.

Mocan E, Tagadiuc O, Nacu V. Aspects of Collagen Isolation Procedure. Clinical Research Studies, 2011; 2: 3-5

Leitinger, B Hohenester E. Mammalian collagen receptors. Matrix Biol. 2007; 26:146-155.

Oliveira S, Ringshia R, Legeros R, ClarkE, Terracio L, Teixeira C, Yost M. An improved collagen scaffold for skeletal regeneration. Journal of Biomedical Materials, 2009; 94 (2): 371-379.

Parenteau-Bareil, R. , Gauvin, R., Berthod, F. Collagen-Based Biomaterials for Tissue Engineering Applications. Materials 2010, 3, 1863-1887.

Badylak SF. Xenogeneic extracellular matrix as a scaffold for tissue reconstruction. Transpl. Immunol, 2004; 12, 367-377.

GIingras, M, Beaulieu, MM, Gagnon V, Durham HD, Berthod F. In vitro study of axonal migration and myelination of motor neurons in a three-dimensional tissue-engineered model. Glia, 2008; 56: 354-364.

Che ZM,Jung TH, Choi JH, Yoon-do J, Jeong HJ, Lee EJ, Kim J. Collagen-based co-culture for invasive study on cancer cells-fibroblasts interaction. Biochem. Biophys. Res. Commun. 2006; 346: 268-275.

Sanz-Herrera JA, Reina-Romo, E. Cell-Biomaterial Mechanical Interaction in the Framework of Tissue Engineering: Insights, Computational Modeling and Perspectives. Int. J. Mol. Sci. 2011, 12, 8217-8244.

Cunniffe GM, Brien FJO. Collagen scaffolds for orthopedic regenerative medicine. The Journalof the Minerals, Met als and Materials Society, 2011; 63 (4): 66-73.

Rose FR, Oreffo RO: Bone tissue engineering: hope vs hype. Biochem Biophys Res Commun 2002, 292:1-7.

\section{How to cite this article:}

Silvipriya KS, Krishna Kumar K, Bhat AR, Dinesh Kumar B, Anish John, Panayappan lakshmanan. Collagen: Animal Sources and Biomedical Application. J App Pharm Sci, 2015; 5 (03): 123127. 